\title{
ANALISIS DAMPAK PEMEKARAN WILAYAH TERHADAP PENDAPATAN PERKAPITA DIKABUPATEN KERINCI
}

\author{
Murniati \\ murniatimsi@gmail.com \\ STIE Sakti Alam Kerinci
}

\begin{abstract}
The Indonesian nation has reformed the governance since the enactment of Law No.22 of 1999 on Regional Government. Since then innovative ideas and experiments have been conducted to improve the implementation of regional autonomy and decentralization in order to improve public services and poverty alleviation effectively. One of the most important aspects of the current implementation of regional autonomy is related to the division and merger of regions which aims to strengthen the relationship between local government and local communities in order to grow democratic life. Kerinci regency is one of the districts located at the western end of Jambi Province. This regency is one of the oldest districts in Jambi Province which has been established as a district in Jambi Province since the province was officially established. Kota Sungai Penuh is an expansion of Kerinci Regency established through Law Number 25 Year 2008 regarding the Formation of Full River City in Jambi Province. Based on the results and discussion it can be concluded that this study proves that there is a difference of Per Capita income in Kerinci Regency 2005-2013, four years before pemekaran (2005-2008) with four years after pemekaran (2010-2013), this is proved by Count> t table or 9.991> 3.18245. There needs to be a more targeted program and policy making for the development of Kerinci Regency and the economic development of the community as well as resolving the economic problems that exist in Kerinci regency so that pemekaran is not merely limited to the formulation of articles related to eligibility, and the process of expansion but also policy Which is able to meet the needs of the community and the development of the Regency in order to move forward. The need for support from all parties for the successful development of both community, private, political policy and government of Kerinci Regency.
\end{abstract}

Keyword : the implementation of regional autonomy and decentralization

\section{PENDAHULUAN}

Kabupaten Kerinci merupakan salah satu kabupaten yang terdapat di bagian ujung barat dari Propinsi Jambi. Kabupaten ini merupakan salah satu kabupaten tertua di Propinsi Jambi dimana telah ditetapkan menjadi kabupaten di Propinsi Jambi semenjak propinsi ini resmi dibentuk. Sebelum Pemekaran wilayah Kabupaten Kerinci terdiri dari 16 Kecamatan, yang terdiri dari : 1. Gunung Tujuh 2. Kayu Aro 3. Kayu Aro barat 4. Gunung Kerinci 5. Siulak 6. Siulak Mukai 7. Air Hangat 8. Air Hangat Barat 9. Depati VII 10. Air Hangat Timur 11. Sitinjau Laut 12. Danau Kerinci 13. Keliling Danau 14. Gunung Raya 15. Bukit Kerman 16. Batang Merangin

Kota Sungai Penuh merupakan merupakan pemekaran dari Kabupaten Kerinci yang dibentuk melalui Undang-Undang Nomor 25 Tahun 2008 tentang Pembentukan Kota Sungai Penuh di Provinsi Jambi. beberapa bekas kecamatan di Kabupaten Kerinci ditetapkan untuk menjadi bagian dari Kota Sungaipenuh. Kecamatan-kecamatan yang dimaksud adalah (1)Hamparan Rawang, (2) Kumun 
Debai (3) Pesisir Bukit (4) Sungai Penuh (5)Tanah Kampung. Adapun kronologis Pemekaran Wilayah Kabupaten Kerinci dimekarkan menjadi Kabupaten Kerinci dan Kota Sungai Penuh sebagai berikut:

1. Keputusan Pemerintah Kerajaan Belanda (Government Besluit) Nomor 13 tanggal 03 November 1909, Sungai Penuh ditunjuk sebagai Ibukota

2. Aspirasi masyarakat membentuk Kota Sungai Penuh sejak tahun 1970-an

3. Perkembangan Kota Sungai Penuh tidak efektif dikelola hanya oleh

4. pemerintah kecamatan

5. Kota Sungai Penuh merupakan kota terpadat kedua di Provinsi Jambi setelah Kota Jambi

6. Peraturan Pemerintah Nomor 129 tahun 2000 tentang persyaratan pembentukan dan kriteria pemekaran, penghapusan dan penggabungan daerah

7. Untuk peningkatan pelayanan publik dan percepatan pembangunan

8. Hasil peneli tian oleh Sadu Wasistiono (Pasca Sarjana IPDN) tahun 2005 yang menyatakan bahwa Kabupaten Kerinci layak untuk dimekarkan.

Harapan Pemekaran daerah bisa menjadi sasaran fungsi pembangunan yang diarahkan pada upaya-upaya untuk meningkatkan partisipasi masyarakat dalam pelaksanaan pembangunan, menciptakan kemandirian masyarakat, peningkatan kemampuan dan sumber daya aparatur dalam penyelenggaraan pemerintahan dan peningkatan pengembangan usaha ekonomi masyarakat.

Komposisi penduduk Kabupaten Kerinci terdiri dari Laki-laki sebanyak 154.227 jiwa (49,53 \%) dan Perempuan sebanyak 157.127 jiwa (50,47 \%) dengan Rasio 98 sedangkan pertumbuhan penduduk sebesar 0,83 Rendahnya pertumbuhan Penduduk disebabkan Karena keberhasilan program Keluarga Berencana di daerah tersebut yang mulai digalakkan pada tahun 1979. Di samping itu adanya sebagian penduduk Kabupaten Kerinci yang menjadi Tenaga Kerja di luar daerah dan luar negeri seperti di Malaysia, Singapura, Taiwan, Korea dan Jepang. Pada Tabel di bawah ini bisa dilihat data dari PDRB dari tahun 2009 sampai dengan 2013 :

\section{Laju Pertumbuhan Ekonomi Kabupaten Kerinci} Tahun 2009-2013 (Dalam Juta Rupiah)

\begin{tabular}{|l|l|l|l|}
\hline No & Tahun & PDRB & Pertumbuhan \\
\hline 1 & 2009 & 1.059 .597 & - \\
\hline 2 & 2010 & 1.121 .988 & 5,888 \\
\hline 3 & 2011 & 1.186 .144 & 5,718 \\
\hline 4 & 2012 & 1.263 .853 & 6,551 \\
\hline 5 & 2013 & 1.345 .250 & 6,440 \\
\hline & & 5.976 .832 & 24,598 \\
\hline
\end{tabular}

Sumber : BPS Kabupaten Kerinci tahun 2013 


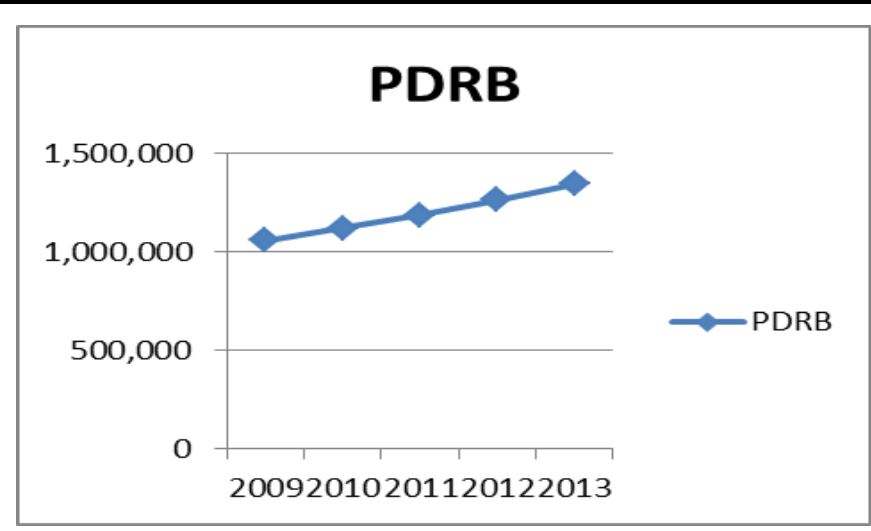

Jika dilihat selama kurun waktu lima tahun terakhir (2009-2013), pertumbuhan ekonomi Kabupaten Kerinci mengalami kecenderungan meningkat, yakni pada tahun 2010 pertumbuhan ekonomi Kabupaten Kerinci sekitar 5,888 persen, kemudian pada tahun 2011 tumbuh menjadi sekitar 5,718 persen dan meningkat lagi pada tahun berikutnya sekitar 6,551 persen, pada tahun 2013 pertumbuhan ekonomi Kabupaten Kerinci yaitu sekitar 6,440 persen. Hal ini menggambarkan keadaan perekonomian Kabupaten Kerinci yang membaik dan cukup stabil.

Berdasarkan uraian diatas, penulis tertarik untuk mencoba melakukan penelitian dengan menganalisa sudah sejauh mana pemekaran yang terjadi di Kabupaten Kerinci yang merupakan daerah induk memberikan pengaruh terhadap tingkat sosial ekonomi masyarakatnya. Dalam hal ini Penulis mencoba menuangkannya melalui penulisan Penelitian dengan judul "Analisis Dampak Pemekaran Wilayah terhadap Pendapatan Perkapita di Kabupaten Kerinci".

Berdasarkan latar belakang diatas, rumusan masalah dalam penelitin ini adalah Bagaimanakah dampak pemekaran wilayah terhadap pendapatan perkapita di Kabupaten Kerinci?

Tujuan penelitian ini adalah untuk mengetahui dampak pemekaran wilayah terhadap pendapatan perkapita di Kabupaten Kerinci.

Penelitian ini diharapkan bermanfaat bagi pemerintah Kabupaten Kerinci dalam mengambil kebijakan yang berhubungan dengan Pendapatan Perkapita yang diterima oleh pemerintah Kabupaten Kerinci.

\section{LANDASAN TEORI}

\section{Pemekaran Wilayah}

Bangsa Indonesia melakukan reformasi tata pemerintahan semenjak diberlakukannya UU No.22 Tahun 1999 tentang Pemerintahan Daerah. Sejak saat itu berbagai pemikiran inovatif dan uji coba terus dilakukan sebagai upaya untuk menyempurnakan pelaksanaan otonomi daerah dan desentralisasi dalam rangka peningkatan pelayanan publik dan penanggulangan kemiskinan secara efektif.

Salah satu aspek yang sangat penting dari pelaksanaan otonomi daerah saat ini adalah terkait dengan pemekaran dan penggabungan wilayah yang bertujuan untuk memperkuat hubungan antara pemerintah daerah dan masyarakat lokal dalam rangka pertumbuhan kehidupan demokrasi. Dengan interaksi yang lebih intensif antara masyarakat dan pemerintah daerah baru, maka masyarakat sipil akan memperoleh hak-hak dan kewajiban-kewajibannya secara lebih baik sebagai warga negara.

Berdasarkan Undang-Undang Pemerintah yang dimaksud Pemerintahan Daerah adalah penyelenggaraan urusan pemerintahan oleh pemerintah daerah dan 
dewan perwakilan rakyat daerah menurut asas otonomi dan tugas pembantuan dengan prinsip otonomi seluas-luasnya dalam sistem dan prinsip Negara Kesatuan Republik Indonesia sebagaimana dimaksud dalam Undang-Undang Dasar Negara Republik Indonesia Tahun 1945. Sedangkan, Pemerintah Daerah adalah kepala daerah sebagai unsur penyelenggara Pemerintahan Daerah yang memimpin pelaksanaan urusan pemerintahan yang menjadi kewenangan daerah otonom. Otonomi Daerah adalah hak, wewenang, dan kewajiban daerah otonom untuk mengatur dan mengurus sendiri Urusan Pemerintahan dan kepentingan masyarakat setempat dalam sistem Negara Kesatuan Republik Indonesia. Serta Asas Otonomi adalah prinsip dasar penyelenggaraan Pemerintahan Daerah berdasarkan Otonomi Daerah. Desentralisasi adalah penyerahan Urusan Pemerintahan oleh Pemerintah Pusat kepada daerah otonom berdasarkan Asas Otonomi.

Menurut Tarigan (2005) dalam Malik (2006), bahwa wilayah dapat dibedakan berdasarkan cara pandang terkait dengan kondisinya atau berdasarkan fungsinya, yaitu :

1. Wilayah subjektif, yakni wilayah merupakan alat untuk mengidentifikasi suatu lokasi yang berdasarkan suatu lokasi dengan kriteria tertentu dan tujuan tertentu.

2. Wilayah objektif, maksudnya wilayah itu benar-benar ada dan dapat dibedakan dari ciri-ciri atau gejala alam di setiap wilayah.

Blair (1991) dalam Malik (2006) menyebutkan bahwa dalam menganalisis wilayah dikenal 3 tipe, yakni :

1. Wilayah fungsional, yaitu adanya saling interaksi antara komponen-komponen didalam dan diluar wilayahnya. Wujud wilayah sering disebut wilayah nodal yang didasari oleh susunan dari suatu hubungan di antara simpul-simpul perdagangan.

2. Wilayah homogen, artinya adanya relatif kemiripan dalam suatu wilayah.

3. Wilayah administratif, artinya wilayah ini dibentuk untuk kepentingan wilayah pengelolaan atau organisasi oleh pemerintah maupun pihak-pihak lain.

Sementara itu, tujuan wilayah menurut Sihotang (1997) dalam Malik (2006) adalah sebagai suatu usaha untuk menentukan batas-batas daerah yang biasanya lebih besar daripada daerah struktur pemerintahan lokal, dengan maksud lebih mengefektifkan dan mengefisienkan pemerintah beserta perencanaan lokal dan nasionalnya.

Secara umum, pemekaran wilayah merupakan suatu proses pembagian wilayah menjadi lebih dari satu wilayah, dengan tujuan meningkatkan pelayanan dan mempercepat pembangunan. Terdapat beberapa alasan mengapa pemekaran wilayah sekarang menjadi salah satu pendekatan yang cukup diminati dalam kaitannya dengan penyelenggaraan pemerintahan daerah dan peningkatan pelayanan publik, yaitu:

1. Alasan mendekatkan pelayanan kepada masyarakat.

Hal ini dijadikan alasan utama karena adanya kendala geografis, infrastruktur dan sarana perhubungan yang minim.

2. Alasan historis.

Pemekaran suatu daerah dilakukan karena alasan sejarah, yaitu bahwa daerah hasil pemekaran memiliki nilai historis tertentu.

3. Alasan kultural atau budaya (etnis).

Pemekaran daerah terjadi karena menganggap adanya perbedaan budaya antara daerah yang bersangkutan dengan daerah induknya. 
4. Alasan ekonomi.

Pemekaran daerah diharapkan dapat mempercepat pembangunan di daerah.

5. Alasan anggaran.

Pemekaran daerah dilakukan untuk mendapatkan anggaran dari pemerintah. Sebagaimana diketahui daerah yang dimekarkan akan mendapatkan anggaran dari daerah induk selama 3 tahun dan mendapatkan dana dari pemerintah pusat (DAU dan DAK).

6. Alasan keadilan.

Pemekaran dijadikan alasan untuk mendapatkan keadilan. Artinya, pemekaran daerah diharapkan akan menciptakan keadilan dalam hal pengisian jabatan pubik dan pemerataan pembangunan.

Disisi lain, menurut Syafrizal (2008) dalam Ventauli (2009), ada beberapa faktor yang dapat memicu terjadinya pemekaran wilayah, antara lain :

\section{Perbedaan agama}

Kenyataan yang terjadi dalam masyarakat menunjukkan bahwa perbedaan agama merupakan salah satu unsur yang dapat menyebabkan timbulnya keinginan masyarakat untuk memisahkan diri dari suatu negara/ daerah yang telah ada untuk menjadi negara/ daerah baru.

2. Perbedaan etnis dan budaya

Sama halnya dengan perbedaan agama, perbedaan etnis dan budaya juga merupakan unsur penting lainnya yang dapat memicu terjadinya keinginan untuk melakukan pemekaran wilayah. Kenyataan menunjukkan bahwa masyarakat merasa kurang nyaman bila hidup dalam suatu masyarakat dengan etnis, adat istiadat, dan kebiasaan yang berbeda. Bila kesatuan budaya ini terganggu karena kehadiran warga masyarakat lain dengan budaya yang berbeda, maka seringkali terjadi ketegangan bahkan konflik sosial dalam masyarakat tersebut.

3. Ketimpangan pembangunan ekonomi antar daerah

Aspek berikutnya yang cenderung menjadi pemicu terjadinya pemekaran wilayah adalah ketimpangan pembangunan ekonomi antar daerah. Termasuk juga ke dalam aspek ini adalah ketimpangan dalam ketersediaan sumber daya alam bernilai tinggi, seperti minyak bumi, gas alam, dan batu bara yang selanjutnya akan mendorong terjadinya ketimpangan kemakmuran antar daerah. Ketimpangan ini selanjutnya mendorong terjadinya kecemburuan sosial dan merasa dianaktirikan oleh pemerintah pusat sehinnga akhirnya muncul keinginan untuk melakukan pemekaran wilayah. Indikasi terjadinya ketimpangan pembangunan antar daerah dapat diketahui dengan menghitung data PDRB perkapita dan jumlah penduduk sebagai indikator utama melalui Indeks Wiliamson.

4. Luas daerah

Luas daerah dapat pula memicu timbulnya keinginan untuk melakukan pemekaran wilayah. Alasannya adalah karena wilayah yang besar akan cenderung menyebabkan pelayanan public tidak dapat dilakukan secara efektif dan merata ke seluruh pelosok daerah. Sementara tugas pemerintah daerah adalah memberikan pelayanan publik kepada seluruh masyarakat di daerahnya. Dalam rangka memperbaiki pelayanan kepada masyarakat, maka salah satu cara yang dapat ditempuh adalah dengan melakukan pemekaran daerah.

Pemekaran wilayah diharapkan dapat menciptakan kemandirian daerah. Tujuan pemekaran sebagaimana tertuang dalam berbagai peraturan perundangan dimaksudkan untuk meningkatkan kesejahteraan masyarakat melalui: 
1. Peningkatan pelayanan kepada masyarakat

2. Percepatan pertumbuhan kehidupan demokrasi

3. Percepatan pelaksanaan pembangunan perekonomian daerah

4. Percepatan pengelolaan potensi daerah

5. Peningkatan keamanan dan ketertiban

6. Peningkatan hubungan yang serasi antara pusat dan daerah

Selanjutnya, syarat teknis dari pembentukan daerah baru harus meliputi faktor yang menjadi dasar pembentukan daerah yang mencakup faktor-faktor di bawah ini, antara lain :

1. Kemampuan ekonomi, merupakan cerminan hasil kegiatan usaha perekonomian yang berlangsung disuatu daerah propinsi, kabupaten/kota, yang dapat diukur dari Produk Domestik Regional Bruto (PDRB) dan penerimaan daerah sendiri.

2. Potensi daerah, merupakan cerminan tersedianya sumber daya yang dapat dimanfaatkan dan kesejahteraan masyarakat yang dapat diukur dari lembaga keuangan, sarana ekonomi, sarana pendidikan, sarana kesehatan, sarana transportasi dan komunikasi, sarana pariwisata dan ketenagakerjaan.

3. Sosial budaya, merupakan cerminan yang berkaitan dengan struktur sosial dan pola budaya masyarakat, kondisi sosial masyarakat yang dapat diukur dari tempat peribadatan, tempat kegiatan institusi sosial dan budaya, serta sarana olahraga.

4. Sosial politik, merupakan cerminan kondisi sosial politik masyarakat yang dapat diukur dari partisipasi masyarakat dalam politik dan organisasi kemasyarakatan.

5. Kependudukan, merupakan jumlah total penduduk suatu daerah.

6. Luas daerah, merupakan luas tertentu suatu daerah.

7. Pertahanan dan keamanan

8. Faktor-faktor lain yang memungkinkan terselenggaranya otonomi daerah.

Pembentukan Daerah dalam Undang-Undang tentang pemerintahan Daerah menyatakana. pemekaran Daerah berupa:

1. pemecahan Daerah provinsi atau Daerah kabupaten/kota untuk menjadi dua atau lebih Daerah baru; atau

2. penggabungan bagian Daerah dari Daerah yang bersanding dalam 1 (satu) Daerah provinsi menjadi satu Daerah baru.

Pemekaran Daerah dilakukan melalui tahapan Daerah Persiapan provinsi atau Daerah Persiapan kabupaten/kota. Pembentukan Daerah Persiapan harus memenuhi persyaratan dasar dan persyaratan administratif.

\section{Pendapatan Perkapita}

Pendapatan per Kapita adalah pendapatan rata-rata penduduk suatu negara pada suatu periode tertentu, yang biasanya satu tahun. Pendapatan per kapita bisa juga diartikan sebagai jumlah dari nilai barang dan jasa rata-rata yang tersedia bagi setiap penduduk suatu negara pada periode tertentu. Pendapatan per kapita diperoleh dari pendapatan nasional pada tahun tertentu dibagi dengan jumlah penduduk suatu negara pada tahun tersebut.

Pembangunan ekonomi didefinisikan sebagai suatu proses yang menyebabkan kenaikan pendapatan riil per kapita penduduk suatu negara dalam jangka panjang, yang disertai oleh perbaikan sistem kelembagaan (Arsyad, 1999 dalam Admin, 2007). Dari definisi tersebut pembangunan ekonomi mempunyai pengertian:

1. Suatu proses yang berarti perubahan yang terjadi secara terus menerus. 
2. Usaha untuk meningkatkan pendapatan perkapita.

3. Kenaikan pendapatan per kapita tersebut harus terus berlangsung dalam jangka panjang.

4. Perbaikan sistem kelembagaan di segala bidang.

Pembangunan ekonomi akan tercermin pada kenaikan pendapatan perkapita dan perbaikan tingkat kesejahteraan pada masyarakat. Indikator dari laju pertumbuhan ekonomi suatu negara salah satunya ditunjukkan dengan tingkat Pertumbuhan Domestik Bruto atau Produk Nasional Bruto. Keberhasilan pembangunan ekonomi menurut Todaro (dalam Admin, 2001) ditunjukkan oleh tiga nilai pokok yaitu:

a. Perkembangan masyarakat untuk memenuhi kebutuhan pokoknya basic needs.

b. Meningkatkan rasa harga diri self-esteem masyarakat sebagai manusia

c. Meningkatnya kemampuan masyarakat untuk memilih freedom from servitude yang merupakan salah satu dari hak asasi manusia.

Pendapatan per kapita adalah pendapatan rata-rata penduduk suatu negara pada waktu tertentu, yang biasanya satu tahun. Nilai diperoleh dari membagi nilai Produk Nasional Bruto atau Produk Domestik Bruto tahun tertentu dengan jumlah produk pada tahun tertentu. Pada umumnya untuk mengetahui laju pembangunan ekonomi suatu negara dan perkembangan tingkat kesejahteraan masyarakatnya, perlu diketahui tingkat pertambahan pendapatan nasional dan besarnya pendapatan per kapita. Besarnya pendapatan nasional akan menentukan besarnya pendapatan per kapita.

Pendapatan per kapita yang merupakan salah satu prestasi ekonomi sangat erat kaitannya dengan pertambahan penduduk. Sehingga apabila pertambahan pendapatan nasional lebih besar daripada pertambahan penduduk maka tingkat pendapatan per kapita penduduk meningkat. Sebaliknya apabila pertambahan pendapatan nasional lebih kecil dari pertambahan penduduk maka pendapatan per kapita mengalami penurunan. Untuk mempertahankan tingkat per kapita relatif perlu dicapai tingkat pertambahan nasional yang sama dengan tingkat pertambahan penduduk. Pendapatan nasional dan pendapatan per kapita itu sendiri akan naik apabila produktivitas perkapita mengalami kenaikan. Untuk menaikkan produktivitas per kapita berarti harus ada perubahan-perubahan dalam perekonomian misalnya perubahan struktur ekonomi, teknik produksi, sruktur produksi dan masyarakat statis berkembang menjadi masyarakat dinamis.

Faktor- Faktor yang Menyebabkan Rendahnya Pendapatan Per Kapita

Faktor yang menyebabkan rendahnya pendapatan Per kapita pada Negara yang sedang berkembang:

a. Tingakat pendidikan rendah sehingga pengetahuaanya sedikit.

b. Ketrampilan dan Kecakapan yang rendah,sehingga kekurangan tenaga ahli.

c. Modal yang dimiliki terlalu sedikit.

d. Kekurangan akan sumber daya alam.

e. Kemalasan dan ketidak disiplinan seseorang

f. Sikap yang tidak mau berproduksi.

g. Pendapatan nasional yang rendah.

\section{Upaya Meningkatkan Pendapatan Per Kapita}

a. Laju pertumbuhan ekonomi harus ditingkatkan agar pendapatan nasional meningkat

a. Laju pertumbuhan penduduk perlu untuk dikendalikan. Pemerintah menyadari keterbatasan dalam meningkatkan kualitas sumber daya manusia. Oleh karena itu, peningkatan pendapatan nasional perlu diimbangi dengan usaha menekan 
kenaikan jumlah penduduk. Dengan menekan laju pertumbuhan penduduk, diharapkan kenaikan jumlah penduduk tidak tidak melebihi kenaikan pendapatan nasional. Dengan demikian, setiap kenaikan pendapatan nasional akan dapat memperbaiki tingkat pendapatan per kapita. Jadi, jelas bahwa usaha meningkatkan pendapatan nasional tidak bersiri sendiri. Agar dapat memberikan perbaikan dalam hal pendapatan per kapita, usaha meningkatkan pendapatan nasional harus diimbangi dengan pengendalian jumlah penduduk. Apabila tisak, usaha meningkatkan pendapatan nasional untuk memperbsiki pendapatan per kapita akan sia-sia.

b. Meningkatkan sumber daya manusia juga bukan hal yang mudah. Dana yang diperlukan untuk itu sangat besar, misalnya untuk pendidikan, latihan, dan peningkatan kesehatan. Besarnya dana yang terserap itu berarti mengurangi kemampuan Negara untuk menyediakan modal yang dapat menambah produksi.

Secara matematis, rumus perhitungan Pendapatan per kapita adalah $=$ Pendapatan Nasional Bruto (GNP)

Jumlah Penduduk

Pendapatan per kapita (per capita income) adalah pendapatan rata-rata penduduk suatu negara pada suatu periode tertentu, yang biasanya satu tahun. Pendapatan per kapita bisa juga diartikan sebagai jumlah dari nilai barang dan jasa rata-rata yang tersedia bagi setiap penduduk suatu negara pada suatu periode tertentu. Pendapatan per kapita diperoleh dari pendapatan nasional pada tahun tertentu dibagi dengan jumlah penduduk suatu negara pada tahun tersebut.

\section{METODOLOGI PENELITIAN}

\section{Metode Pengumpulan Data}

Pengumpulan data dilakukan dengan cara (1) Penelitian Pustaka (Library Research) yaitu suatu teknik untuk mendapatkan data teoritis atau data sekunder dalam penelitian. Penelitian kepustakaan dilakukan dengan cara mempelajari buku-buku, literatur, dokumen-dokumen resmi, catatan dan transkrip, yang berkaitan dengan penelitian ini (2) Penelitian Lapangan (Field Research) yaitu penelitian langsung kelapangan dalam rangka mendapatkan data yang berhubungan dengan masalah yang diteliti

\section{Metode Analisis}

Pada penelitian ini menggunakan metode deskriptif kuantitatif yang merupakan analisis metode yang merupakan alat untuk meneliti dengan melakukan perhitungan-perhitungan yang berkaitan dengan permasalahan yang akan diteliti.

\section{Alat Analisis Data}

Dalam penelitian yang dilakukan, data yang telah diperoleh akan dianalisis dengan menggunakan alat analisis sebagai berikut:

a. Pendapatan Perkapita

\begin{tabular}{|l|c|}
\hline \multirow{2}{*}{ PDRB Perkapita $=$} & PDRB \\
\cline { 2 - 2 } & Jumlah Penduduk \\
\hline
\end{tabular}

\section{Hipotesis}

$\mathrm{H}_{\mathrm{O}}: \mathrm{r}=0$ Artinya bahwa diduga tidak terdapat perbedaan yang signifikan antara a perkapita di kabupaten Kerinci pada saat sebelum dan sesudah pemekaran wilayah. 
Ha $: r \neq 0 \quad$ Artinya bahwa diduga terdapat perbedaan yang signifikan antara Pendapatn perkapita di kabupaten Kerinci pada saat sebelum dan sesudah pemekaran wilayah.

\section{Uji Hipotesis (Uji paired sample test)}

Pengujian statistik dilakukan dengan menguji Pendapatn perkapita di kabupaten Kerinci sebelum dan sesudah pemekaran wilayah, dengan hasil pengujian ini diharapkan dapat mengetahui apakah terdapat perbedaan Pendapatn perkapita di kabupaten Kerinci sebelum dan sesudah pemekaran wilayah.

Uji paired sample test digunakan untuk menguji apakah ada perbedaan Pendapatan perkapita di kabupaten Kerinci sebelum dan sesudah pemekaran wilayah. Paired samples t-test atau uji $\mathrm{T}$ sampel berpasangan merupakan uji parametrik yang digunakan untuk menguji hipotesis sama atau tidak berbeda (Ho) diantara dua variabel. Data berasal dari dua pengukuran atau dua periode pengamatan yang berbeda yang diambil subjek yang dipasangkan yakni sebelum pemekaran wilayah dan sesudah pemekaran wilayah. Santoso (2000) menjelaskan langkah-langkah penggunaan uji t untuk pengujian sampel berpasangan sebagai berikut :

1. Menghitung selisih (d) antara pengamatan sebelum dan sesudah

2. Menghitung total d ( $\Sigma \square \mathrm{d}$ ), lalu mencari mean d, yaitu $\frac{\sum d}{n}$

3. Menghitung d- (d rata-rata), kemudian mengkuadratkan selisih tersebut dan menghitung total selisih kuadrat.

4. Mencari standar deviasi dengan rumus sebagai berikut :

$$
\mathrm{Sd}=\left(\frac{1}{n-1}\right) \times\left[\text { total }_{(\mathrm{d}-\mathrm{d} \text { rata-rata })]^{2}}\right.
$$

5. Menghitung thitung dengan rumus :

$$
\mathrm{t}=\frac{(x 1-x 2)-\sqrt{p}}{\frac{s d}{\sqrt{n}}}
$$

Keterangan :

$(\mathrm{x} 1-\mathrm{x} 2)=$ Rata-rata hitung pengamatan atau sampel untuk pengamatan sebelum dan pengamatan sesudah pemekaran wilayah

x $1=$ Rata-rata hitung pengamatan atau sampel sebelum pemekaran wilayah

x $2=$ Rata-rata hitung pengamatan atau sampel setelah pemekaran wilayah

$\square \square \mathrm{p}=$ Rata-rata hitung populasi yang dihipotesiskan, ditetapkan bernilai nol (0)

Sd = Standar deviasi pengamatan terhadap sampel data pemekaran wilayah

$\mathrm{N}=$ Jumlah pengamatan sampel

Hasil perhitungan dengan nilai $\mathrm{t}_{\text {tabel }}$ dengan taraf kesalahan $\alpha 5 \%$ dengan tingkat kepercayaan 95\%, dengan kaidah pengujian signifikasi :

1. Jika $\mathrm{t}_{\text {hitung }}>\mathrm{t}_{\text {tabel}}$, maka total Ho ditolak dan Ha diterima artinya terdapat perbedaan yang signifikan antara Pendapatan perkapita di kabupaten Kerinci sebelum dan sesudah pemekaran wilayah

2. Jika $\mathrm{t}_{\text {Hitung }}<\mathrm{t}_{\text {tabel }}$, Maka total Ho diterima dan Ha ditolak artinya tidak terdapat perbedaan yang signifikan antara Pendapatan perkapita di kabupaten Kerinci sebelum dan sesudah pemekaran wilayah.

Pengolahan data di atas dibantu dengan menggunkan program SPSS 20. 


\section{HASIL DAN PEMBAHASAN}

Hasil Analisis Dampak Pemekaran Wilayah terhadap Pendapatan Perkapita di Kabupaten Kerinci Tahun 2005-2013. Dengan membandingkan data dari Kabupaten Kerinci empat tahun sebelum pemekaran (2005-2008) dengan empat tahun sesudah pemekaran (2010-2013). Adapun pemekaran Kabupaten Kerinci, yang dimekarkan menjadi Kota Sungai Penuh pada 11 November tahun 2009. Data pendapatan perkapita sesuai periode pengamatan diperoleh dari Badan Pusat Statistik (BPS) Kabupaten Kerinci.

\section{Pendapatan Perkapita}

Pendapatan per Kapita adalah pendapatan rata-rata penduduk suatu negara pada suatu periode tertentu, yang biasanya satu tahun. Pendapatan per kapita bisa juga diartikan sebagai jumlah dari nilai barang dan jasa rata-rata yang tersedia bagi setiap penduduk suatu negara pada periode tertentu. Pendapatan per kapita diperoleh dari pendapatan nasional pada tahun tertentu dibagi dengan jumlah penduduk suatu negara pada tahun tersebut. Pada tabel di bawah ini dijelaskan Pendapatan Per Kapita di Kabupaten Kerinci Tahun 2005-2013, empat tahun sebelum pemekaran (2005-2008) dengan empat tahun sesudah pemekaran (20102013) :

Pendapatan Per Kapita di Kabupaten Kerinci

Tahun 2005-2013

\begin{tabular}{ccccc}
\hline No & Tahun & PDRB & Jumlah Penduduk & Pendapatan Perkapita \\
\hline 1 & 2005 & $847.651,97$ & 308.785 & $2.745 .120,29$ \\
2 & 2006 & $892.698,98$ & 311.354 & $2.867 .151,15$ \\
3 & 2007 & $945.310,06$ & 313.634 & $3.014 .054,79$ \\
4 & 2008 & $1.000 .752,04$ & 235.419 & $4.250 .939,98$ \\
& 2009 & & Pemekaran Wilayah \\
5 & 2010 & $1.121 .987,60$ & 229.495 & $4.888 .941,37$ \\
6 & 2011 & $1.186 .143,84$ & 235.251 & $5.042 .035,27$ \\
7 & 2012 & $1.263 .852,56$ & 235.797 & $5.359 .917,90$ \\
8 & 2013 & $1.345 .250,00$ & 236.762 & $5.681 .866,18$ \\
\hline
\end{tabular}

Sumber : Data Diolah Tahun 2013

\section{Analisis Analisis Dampak Pemekaran Wilayah terhadap Pendapatan Perkapita di Kabupaten Kerinci Tahun 2005-2013}

Pada tabel di bawah ini bisa dilihat data dari perhitungan nilai rata-rata Pendapatan Per Kapita di Kabupaten Kerinci Tahun 2005-2013, empat tahun sebelum pemekaran (2005-2008) dengan empat tahun sesudah pemekaran (20102013) :

\section{Paired Samples Statistics Pendapatan Perkapita}

\begin{tabular}{llllll}
\hline & \multicolumn{1}{c}{ Mean } & N & Std. Deviation & Std. Error Mean \\
\hline Pair 1 & $\begin{array}{l}\text { Pendapatan_Perkapi } \\
\text { ta_Sebelum_Pemek } \\
\text { aran }\end{array}$ & 3219316,5525000 & 4 & 696482,07763455 & 348241,03881727 \\
& $\begin{array}{l}\text { Pendapatan_Perkapi } \\
\text { ta_Sesudah_Pemeka } \\
\text { ran }\end{array}$ & 5243190,1800000 & 4 & 352144,62502213 & 176072,31251106 \\
\hline \multicolumn{2}{l}{ Dari perhitungan nilai rata-rata Pendapatan Per Kapita di Kabupaten Kerinci }
\end{tabular}

Tahun 2005-2013, empat tahun sebelum pemekaran 3219316,55 dengan empat 
tahun sesudah pemekaran (2010-2013) 5243190,18. Jadi pendapatan perkapita meningkat sesudah Kabupaten Kerinci melakukan pemekaran wilayah. Sedangkan pada tabel di bawah ini, bisa dilihat data dari uji beda (Uji paired sample test) Pendapatan Per Kapita di Kabupaten Kerinci Tahun 2005-2013, empat tahun sebelum pemekaran (2005-2008) dengan empat tahun sesudah pemekaran (20102013) :

Paired Samples Test Pendapatan Perkapita

Paired Samples Test

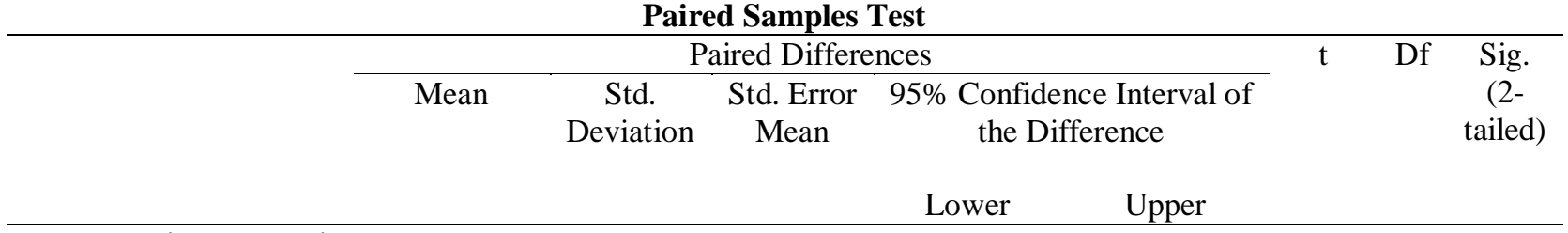

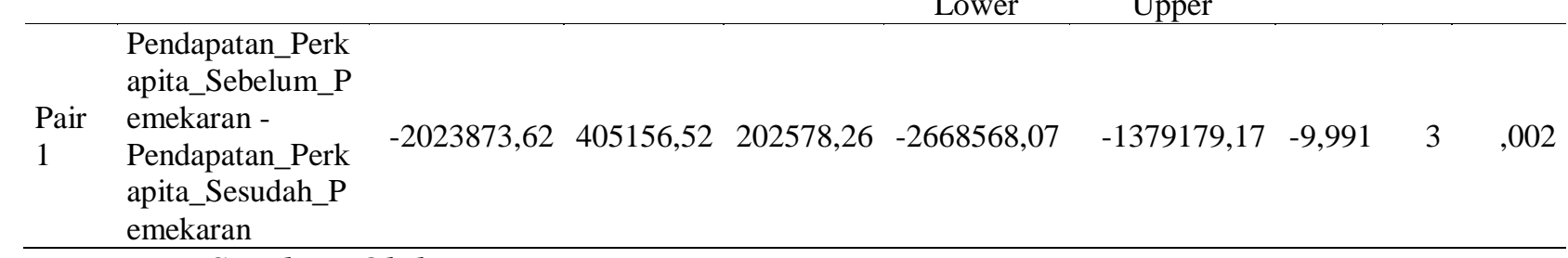

\section{Sumber: Olahan Data}

Nilai t hitung adalah -9,991 dan t tabel adalah - 3,18245, dikarenakan uji dua arah, maka berada pada daerah Ho ditolak dan Ha diterima artinya terdapat perbedaan antara rata-rata Pendapatan Per Kapita di Kabupaten Kerinci Tahun 2005-2013, empat tahun sebelum pemekaran (2005-2008) dengan empat tahun sesudah pemekaran (2010-2013). Laba yang diuji dengan metode paired sample ttest pada periode perbandingan 4 tahun sebelum dengan 4 tahun sesudah pemekaran wilayah diperoleh nilai signifikansi sebesar 0,02 (lebih kecil dari 0,05), maka dapat disimpulkan bahwa terdapat perbedaan antara rata-rata Pendapatan Per Kapita di Kabupaten Kerinci Tahun 2005-2013, empat tahun sebelum pemekaran (2005-2008) dengan empat tahun sesudah pemekaran (20102013).

\section{SIMPULAN DAN SARAN}

\section{Simpulan}

Berdasarkan dari hasil dan pembahasan dapat ditarik kesimpulan bahwa Penelitian ini membuktikan bahwa terdapat perbedaan Pendapatan Per Kapita di Kabupaten Kerinci Tahun 2005-2013, empat tahun sebelum pemekaran (20052008) dengan empat tahun sesudah pemekaran (2010-2013), ini dibuktikan dengan $\mathrm{t}_{\text {hitung }}>\mathrm{t}_{\text {tabel }}$ atau $9,991>3,18245$

\section{Saran}

Perlu adanya program dan pembuatan kebijakan yang lebih tepat sasaran untuk pembangunan Kabupaten Kerinci dan pengembangan ekonomi masyarakat serta penyelesaian masalah ekonomi yang ada di daerah Kabupaten Kerinci sehingga pemekaran yang tidak semata terbatas pada perumusan pasal-pasal yang terkait dengan kelayakan, dan proses pemekaran tetapi juga kebijakan yang mampu untuk memenuhi kebutuhan masyarakat dan perkembangan Kabupaten agar bisa maju. Perlunya dukungan dari semua pihak untuk kesuksesan pembangunan baik masyarakat, swasta, kebijakan politik dan pemerintah Kabupaten Kerinci. 


\section{DAFTAR PUSTAKA}

BPS Kabupaten Kerinci. Produk Domestik Regional Menurut Lapangan Usaha Kabupaten Kerinci Tahun 2005-2013. Biro Pusat Statistik Kabupaten Kerinci 2010.

Kuncoro, Mudrajad, 2014. Otonomi Daerah Menuju Era Bary Pembangunan Daerah, Fakultas Ekonomi Universitas Gadjah Mada Jogyakarta, Jakarta 2014.

Mangkusubroto, Guritno, 2001. Ekonomi Publik. Penerbit BPFE-UGM, Yogyakarta

Nordhaus, William, 2004, Ilmu Makro Ekonomi, Penerbit LP3ES, Jakarta.

Riduan, 2009 . Statistika Untuk Penelitian Penerbit Alfabeta, Bandung.

Sjafrizal. Ekonomi Regional Teori dan Aplikasi. Baduose Media. Padang. 2008.

Sadono Sukirno, Ekonomi pembangunan (Proses, Masalah, dan Dasar Kebijaksanaan). Fakultas Ekonomi UI dengan Bima Grafika. Jakarta 1985.

Soeratno dan Arsyad Lincolin, Metodologi Penelitian, UPP AMPYKPN, Yogyakarta, 1993. 